\title{
Opioid peptides and pituitary function
}

\author{
A. T. McKnight and H. W. Kosterlitz \\ Unit for Research on Addictive Drugs, Marischal College, Aberdeen AB9 1AS, U.K.
}

\section{Introduction}

A number of in-vitro model systems have been introduced for the study of the action of morphine-like drugs. Their usefulness depends on their relative simplicity, compared to the brain and central nervous system, and on the good correlation observed between potencies in the models and potencies in the whole animal. For example, the contractions of the isolated guineapig ileum and mouse vas deferens to electrical stimulation at low frequencies are inhibited by opiate analgesics due to a reduced release of the motor transmitters acetylcholine (Paton, 1957) and noradrenaline (Henderson, Hughes \& Kosterlitz, 1972) respectively, and the order of potencies in these smooth muscle models correlates well with the analgesic potencies of these drugs (see Kosterlitz \& Waterfield, 1975).

Observations with these and other model systems lead to the belief that the site of action of opiates included a specific receptor in the true, pharmacological sense; but it seemed unlikely to many workers in the field of opiate research that such apparently selective receptors should have been developed by Nature to interact with the opium alkaloids. Accordingly, the idea that the opiate receptors must be receptors for "an endogenous humoral substance" was proposed by Collier (1972).

Experimental support for this hypothesis came shortly afterwards when Akil, Mayer \& Liebskind (1972) reported that analgesia could be produced in rats by electrical stimulation through electrodes implanted in the periaqueductal region of the brain and that this "stimulationevoked analgesia" was reduced by administering the morphine antagonist drug naloxone. These results were taken to mean that the brain contained an endogenous substance which produced a morphine-like analgesic effect by interacting with the opiate receptor and which could be released by electrical stimulation. It was then that concerted efforts commenced in several centres to isolate the endogenous morphine-like substance.

\section{The discovery of the endogenous opioid peptides}

The first attempts to isolate the endogenous ligand for the opiate receptor had been unsuccessful due to the mistaken presumption of chemical similarity to morphine, but in 1975 Hughes reported the isolation from aqueous extracts of brain of a material, 'enkephalin', which was peptide in nature and produced morphine-like responses in the in-vitro model systems. This extract of enkephalin was later shown to contain a mixture of two pentapeptides whose structures were $\mathrm{H}$-Tyr-Gly-Gly-Phe-Met-OH (methionine-enkephalin) and $\mathrm{H}$-Tyr-Gly-Gly-PheLeu-OH (leucine-enkephalin) (Hughes et al., 1975). Hughes et al. recognized that the amino acid sequence of methionine-enkephalin was already known as residues 61 to 65 of $\beta$-lipotropin ( $\beta$ LPH), a 91-amino acid peptide of unknown function which had been isolated 10 years earlier from ovine pituitary ( $\mathrm{Li}$, Barnafi, Chrétien \& Chung, 1965). The significance of this observation was enhanced when it was shown that the so-called 'C-fragment' of $\beta$-LPH ( $\beta$-endorphin, $\beta$ - 
$\mathrm{LPH}_{61-91}$ ), which itself was present in the pituitary, had the methionine-enkephalin sequence at its $\mathrm{N}$-terminus and also had morphine-like activity (Bradbury, Smyth, Snell, Birdsall \& Hulme, 1976; Lazarus, Ling \& Guillemin, 1976; Li \& Chung, 1976). Other fragments, including $\alpha$ endorphin $\left(\beta-\mathrm{LPH}_{61-76}\right)$ and $\gamma$-endorphin $\left(\beta-\mathrm{LPH}_{61-77}\right)$, have also been isolated from the pituitary and have opioid activity (Guillemin, Ling \& Burgus, 1976; Lazarus et al., 1976), although recent evidence suggests that these may be artefacts of extraction or breakdown products of $\beta$-endorphin, as C-fragment is now known (Rossier et al., 1977a).

It was originally proposed that methionine-enkephalin might be derived from $\beta$-endorphin which in turn was derived from $\beta$-LPH (Hughes et al., 1975) and by analogy that similar precursors might exist for leucine-enkephalin (Hughes et al., 1978). Attractive as this hypothesis may be, there is no experimental evidence in its favour (see McKnight, Sosa, Hughes \& Kosterlitz, 1978). Although $\beta$-endorphin in the pituitary may be derived from $\beta$-LPH (Chretien et al., 1978), the enkephalins in both central and peripheral sites are synthesized locally from as yet unknown precursors (McKnight et al., 1978).

The distributions of the endogenous opioid peptides have been determined by several different techniques and the results suggest that the enkephalins and $\beta$-endorphin form two independent systems.

Enkephalins are widely distributed, both in the brain and the periphery. They are particularly concentrated in the corpus striatum and hypothalamus of guinea-pig brain and the myenteric plexus of guinea-pig small intestine. Although the ratio of the contents of methionine- and leucine-enkephalin varies from region to region, methionine-enkephalin is always present in a greater concentration (Hughes, Kosterlitz \& Smith, 1977). Immunohistochemical studies have shown enkephalin-like immunoreactive material in laminae I and II of the spinal cord, the substantia gelatinosa of the spinal trigemminal nucleus, the vagal nuclei, the periventricular and periaqueductal areas of the upper medulla and midbrain, the dorso-medial thalamus, the globus pallidus and the central nucleus of the amygdala (Elde, Hökfelt, Johansson \& Terenius, 1976; Hökfelt, Elde, Johansson, Terenius \& Stein, 1977; Hökfelt, Ljungdahl, Elde, Nilsson \& Terenius, 1977; Simantov, Kuhar, Uhl \& Snyder, 1977). This immunofluorescence is mainly associated with nerve fibres and terminals which suggests that the enkephalins may be neurotransmitters.

$\beta$-Endorphin is more restricted in its distribution with high concentrations in the anterior and intermediate lobes of the pituitary and lower concentrations in a few brain areas around the midline and in the hypothalamus, thalamus, midbrain and pons (Cox, Goldstein \& $\mathrm{Li}, 1976$; Bloom et al., 1977; Rossier et al., 1977c; Bloom, Battenberg, Rossier, Ling \& Guillemin, 1978).

\section{Physiological significance of the opioid peptides}

When the existence of the enkephalins and $\beta$-endorphin was firmly established, many researchers were interested to examine whether these peptides produced morphine-like analgesia in the standard tests for anti-nociception in animals. The natural enkephalins had only a small and transient effect, even after intracerebroventricular injection (see Pert, Bowie, Fong \& Chang, 1976) while $\beta$-endorphin showed a strong and long-lasting anti-nociceptive action (Feldberg \& Smyth, 1976; Loh, Tseng, Wei \& Li, 1976; Pert, 1976; Tseng, Loh \& Li, 1976). In the mouse tail-flick test, $\beta$-endorphin was 48 times more potent that morphine, on a molar basis, after intracerebroventricular injection and 3.4 times more potent after intravenous injection (Li, 1977). These observations lead several groups to propose that the enkephalins had no physiological significance but rather that they were breakdown products of $\beta$-endorphin, like $\alpha$ - and $\gamma$ endorphin. This idea has largely been rejected since the transience of the effects of enkephalins is now known to be due to their high sensitivity to hydrolysis by aminopeptidases which are widely distributed in the central nervous system (Hambrook, Morgan, Rance \& Smith, 1976; Meek, Yang \& Costa, 1977). Rather, this rapid inactivation of the enkephalins, together with their rapid 
onset of action, would favour the hypothesis that they are neurotransmitters since it would obviously be important to terminate the actions of such a substance rapidly. The prolonged action of $\beta$-endorphin might then favour a hormonal role for this peptide.

Current evidence suggests that the putative neurotransmitter role of the enkephalins is in the tonic, short-term control of release of other transmitters. Such a role would obviously have many applications. The areas of the central nervous system which are rich in enkephalins are closely associated with dopaminergic, noradrenergic, serotoninergic and substance P-containing neuronal systems and have been implicated in sensory transmission, endocrine control, respiration, motor activity and behaviour. Direct evidence in support of this hypothesis of a general control function of enkephalins is accumulating. The enkephalins have been shown to inhibit the release of noradrenaline (Taube, Borowski, Endo \& Starke, 1976) and acetylcholine (Subramanian et al., 1977) from rat brain and of substance P from rat trigemminal nucleus (Jessel \& Iversen, 1977). This role may also extend to the periphery since the stimulationinduced release of acetylcholine from the guinea-pig ileum and of noradrenaline from the mouse vas deferens is reduced by enkephalin (Waterfield, Smokcum, Hughes, Kosterlitz \& Henderson, 1977). The presence of $\beta$-endorphin-like immunoreactive material in the midline pathway in the brain (Bloom et al., 1978) suggests that this peptide may have a similar, if somewhat less widespread, control function. The role of $\beta$-endorphin in the pituitary has been the subject of more intense speculation.

$\beta$-Endorphin may itself be a pituitary hormone. Either $\beta$-endorphin or its putative precursor $\beta$-LPH is stored within secretory granules (Queen, Pinsky \& La Bella, 1976; La Bella, Queen \& Senyshyn, 1977) and plasma levels of $\beta$-endorphin increase in parallel with those of adrenocorticotrophin (ACTH) during stressful procedures in animals (Rossier et al., 1977b; Guillemin et al., 1977). Whether the release of $\beta$-endorphin and ACTH is generally controlled by similar mechanisms is not yet known, but it seems likely that their biosyntheses are closely associated. Recent evidence suggests that they share a common, high molecular weight precursor, "proopiocortin" (Mains, Eipper \& Ling, 1977; Roberts \& Herbert, 1977a, b; Rubinstein, Stein \& Udenfriend, 1978). Also, pituitary levels of both increase after adrenalectomy and both increases are reduced by dexamethasone (Guillemin et al., 1977).

Alternatively, or in addition, $\beta$-endorphin within the pituitary may play some role in the control of hypophysial hormone release or synthesis. This may be a direct action since opiate receptors are present in the pituitary (Simantov \& Snyder, 1977), or may be exerted at the hypothalamic level since the possibility of retrograde transport of hypophysial hormones in the vasculature of the pituitary stalk has recently been demonstrated (Oliver, Mical \& Porter, 1977; Bergland \& Page, 1978).

\section{Evidence for the control of pituitary function by opioid peptides}

The possibility that the opioid peptides may play some part in the control of pituitary hormone release has been considered recently by many groups and many of the well-known effects of morphine and other opiates which pointed to actions on the pituitary are being closely reexamined and re-interpreted in the light of our knowledge of the possibility that such effects may have a physiological significance. In view of the diversity of techniques used, it is hardly surprising that conflicting results have been obtained, but in general the opioid peptides produce responses which are qualitatively similar to those with morphine and are reduced by opiate antagonists. $\beta$-Endorphin is usually more potent than the enkephalins, but with enkephalin analogues which are resistant to enzymic hydrolysis potencies comparable to that of $\beta$ endorphin are obtained.

Bisset, Chowdrey \& Feldberg (1978) have observed an antidiuretic effect with leucineenkephalin, $\mathrm{D}-\mathrm{Ala}^{2} \mathrm{D}$-Leu ${ }^{5}$-enkephalin and $\beta$-endorphin in water-loaded rats similar to that first 
described with morphine in the dog (de Bodo, 1944). These authors showed that the response to leucine-enkephalin was reduced by naloxone and that for the stable enkephalin analogue at least, the antidiuresis was accompanied by an increased excretion of vasopressin-like material in the urine. Weitzman, Fisher, Minick, Ling \& Guillemin (1977) found increased levels of arginine vasopressin in the blood of rabbits after intravenous injection of $\beta$-endorphin, but van Wimersma Greidanus et al. (1979) have claimed that in both normal and water-deprived rats morphine and $\beta$-endorphin produce decreases in plasma levels of arginine vasopressin with a corresponding increase in $\alpha$-melanocyte stimulating hormone. Weitzman et al. (1977) concluded that the release of vasopressin they observed with $\beta$-endorphin was not due to a direct action on the pituitary since no release could be shown in vitro with isolated neural lobes. No information is currently available on possible effects of opiates and opioid peptides on oxytocin release. Clearly, a well controlled and comprehensive study is required before it can be determined whether enkephalins or $\beta$-endorphin are involved in the control of release of posterior pituitary hormones.

More information is available on the effects of opiates and opioid peptides on the release of anterior pituitary hormones. Most attention has been directed towards growth hormone (GH) and prolactin and there is general agreement that the enkephalins and various enkephalin analogues and $\beta$-endorphin, like morphine, produce increased release of both hormones and that these increases are inhibited by opiate antagonists, naloxone and naltrexone (see Cusan et al., 1977; Rivier, Vale, Ling, Brown \& Guillemin, 1977; Shaar, Frederickson, Dininger \& Jackson, 1977). There is one report of release of prolactin from cultured pituitary cells by enkephalin (Lien, Fenichel, Garsky, Sarantakis \& Grant, 1976) but more recent evidence contradicts this and suggests that the release of both $\mathrm{GH}$ and prolactin by morphine and opioid peptides is not due to a direct action on the pituitary (Rivier et al., 1977; Shaar et al., 1977). Grandison \& Guidotti (1977) and Guidotti \& Grandison (1978) concluded that endogenous opioids control the release of prolactin by inhibiting dopaminergic mechanisms in the mediobasal hypothalamus. Their evidence for this is: (1) that naltrexone administration reduces the serum levels of prolactin in intact rats and in rats with deafferentation of the hypothalamus; (2) that dopamine, but not naltrexone, reduces release of prolactin from pituitary halves in vitro; (3) that intrahypothalamic injection of naltrexone reduces, and of $\beta$-endorphin increases, serum prolactin levels; (4) that after dopamine receptor blockade by haloperidol or depletion of dopamine stores by reserpine, serum prolactin levels are increased and that these elevated levels are undiminished by naltrexone. The observation that administration of an opiate antagonist alone reduces the serum concentration of prolactin has been confirmed by other groups who also showed that GH was similarly affected (Bruni, van Vugt, Marshall \& Meites, 1977; Shaar et al., 1977). This is the most convincing evidence for a physiological role of endogenous opioid peptides in the tonic control of the release of $\mathrm{GH}$ and prolactin.

Similar evidence suggests that the release of luteinizing hormone (LH) may be under some form of control by enkephalins or $\beta$-endorphin in the mature male rat (Bruni et al., 1977; Blank, Panerai \& Friesen, 1979). In the female rat naloxone administration produces an increase in serum LH at various stages before puberty but not in the adult. Significantly, oestradiol administration abolishes the naloxone-induced increase in the prepubertal female (Blank et al., 1979).

The results with follicle-stimulating hormone (FSH) are less clear. Morphine has been shown to block the preovulatory surge of FSH as well as of LH in the rat (Pang, Zimmerman \& Sawyer, 1977) but Bruni et al. (1977) have reported that although naloxone does increase serum FSH levels in the male rat, morphine does not produce any significant decrease. Conversely, while morphine and methionine-enkephalin decreased levels of thyroid stimulating hormone, an action blocked by naloxone, naloxone alone did not increase serum levels of this hormone.

In conclusion, the possibility that opioid peptides are involved in the control of pituitary hormone release must now be considered in spite of the comparative paucity of well controlled and systematic studies. The evidence for such a role is best for $\mathrm{GH}$, prolactin and $\mathrm{LH}$, since 
opiate antagonists decrease serum levels of GH and prolactin and increase levels of LH. It remains to be seen whether future studies can produce unequivocally firm evidence that the control of the release of other pituitary hormones is under similar control and whether this action is independent of the various hypothalamic hypophysiotrophic hormones and is generally due to interactions with hypothalamic aminergic neuronal mechanisms.

The work of the Unit for Research on Addictive Drugs is supported by the Medical Research Council, the U.S. National Institute for Drug Abuse (DA 00662) and the U.S. Committee on Problems of Drug Dependence.

\section{References}

Akil, H., Mayer, D.J. \& Liebskind, J.C. (1972) Comparison chez le rat entre l'analgésie induite par stimulation de la substance grise péri-aqueducale et l'analgésie morphinique. C. r. hebd. Séanc. Acad. Sci., Paris D 274, 3603-3605.

Bergland, R.M. \& Page, R.B. (1978) Can the pituitary secrete directly to the brain? (Affirmative anatomical evidence). Endocrinology 102, 1325-1338

Bisset, G.W., Chowdrey, H.S. \& Feldberg, W. (1978) Release of vasopressin by enkephalin. Br. J. Pharmac. 62, 370-371.

Blank, M.S., Panerai, A.E. \& Friesen, H.G. (1979) Opioid peptides modulate luteinizing hormone secretion during sexual maturation. Science, N.Y. 203, 1129-1131.

Bloom, F., Battenberg, E., Rossier, J., Ling, N., Leppaluoto, J., Vargo, T.M. \& Guillemin, R. (1977) Endorphins are located in the intermediate and anterior-lobes of the pituitary glands not in the neurohypophysis. Life Sci. 20, 43-48.

Bloom, F., Battenberg, R., Rossier, J., Ling, N. \& Guillemin, R. (1978) Neurons containing $\beta$ endorphin in rat brain exist separately from those containing enkephalin: Immunocytochemical studies. Proc. natn. Acad. Sci. U.S.A. 75, 1591-1595.

Bradbury, A.F.D., Smyth, D.G., Snell, C.R., Birdsall, N.J.M. \& Hulme, E.C. (1976) C-fragment of lipotropin has a high affinity for brain opiate receptors. Nature, Lond. 260, 793-795.

Bruni, J.F., van Vugt, D., Marshall, S. \& Meites, J. (1977) Effects of naloxone, morphine and methionine enkephalin on serum prolactin, luteinizing hormone, thyroid stimulating hormone and growth hormone. Life Sci. 21, 461-466.

Chrétien, M., Crine, P., Lis, M., Gianoulakis, G., Gossard, F., Benjannet, S. \& Seidah, N.G. (1978) Biosynthesis of beta-endorphin from beta-lipotropin and a larger precursor molecule. In Characteristics and Function of Opioids, pp. 245-258. Eds J. M. van Ree \& L. Terenius. Elsevier/North Holland Biomedical Press, Amsterdam.

Collier, H.O.J. (1972) Pharmacological mechanisms of drug dependence. In Pharmacology and the Future of Man, pp. 65-76. Ed. G. H. Acheson. Karger, Basel.

Cox, B.M., Goldstein, A. \& Li, C.H. (1976) Opioid activity of a peptide $\beta$-lipotropin (61-91) derived from $\beta$-lipotropin. Proc. natn. Acad. Sci. U.S.A. 73, $1821-1823$.
Cusan, L., Dupont, A., Kledzik, G.S., Labrie, F., Coy, D.H. \& Schally, A.V. (1977) Potent prolactin and growth hormone releasing activity of more analogues of Met-enkephalin. Nature, Lond. 268, 544-547.

de Bodo, R.C. (1944) Antidiuretic effect of morphine and its mechanism. J. Pharmac. 82, 74-85.

Elde, R., Hökfelt, T., Johansson, O. \& Terenius, L. (1976) Immunohistochemical studies using antibodies to leucine-enkephalin: initial observations on the nervous system of the rat. Neuroscience 1, 349351.

Feldberg, W. \& Smyth, D.G. (1976) The C-fragment of lipotropin-a potent analgesic. J. Physiol., Lond. 260, 30-31P.

Grandison, L. \& Guidotti, A. (1977) Regulation of prolactin release by endogenous opiates. Nature, Lond. 270, 357-359.

Guidotti, A. \& Grandison, L. (1978) Participation of hypothalamic endorphins in the control of prolactin release. In The Endorphins, Advances in Biochemical Psychopharmacology, vol. 18, pp. 191-198. Eds E. Costa, \& M. Trabucchi. Raven Press, New York.

Guillemin, R., Ling, N. \& Burgus, R. (1976) Endorphines, peptides d'origine hypothalamique et neurohypophysaire à activité morphinomimetique. Isolement et structure moléculaire d' $\alpha$-endorphine. $C$. r. hebd. Séanc. Acad. Sci., Paris D 274, 783-785.

Guillemin, R., Vargo, T., Rossier, J., Ling, N., Rivier, C., Vale, W. \& Bloom, F. (1977) $\beta$-Endorphin and adrenocorticotrophin are secreted concomitantly by the pituitary gland. Science, N.Y. 197, 1367-1369.

Hambrook, J.M., Morgan, B.A., Rance, J.M. \& Smith, C.F.C. (1976) Mode of deactivation of the enkephalins by rat and human plasma and rat brain homogenates. Nature, Lond. 262, 782-783.

Henderson, G., Hughes, J. \& Kosterlitz, H.W. (1972) A new example of a morphine-sensitive neuro-effector junction; adrenergic neurotransmission in the mouse vas deferens. Br. J. Pharmac. 46, 764-766.

Hökfelt, T., Elde, R., Johansson, O., Terenius, L. \& Stein, L. (1977) The distribution of enkephalinimmunoreactive cell bodies in the rat central nervous system. Neuroscience Letters 5, 25-30.

Hökfelt, T., Ljungdahl, A., Elde, R., Nilsson, G. \& Terenius, L. (1977) Immunohistochemical analysis of peptide pathways possibly related to pain and analgesia: Enkephalin and substance P. Proc. natn. Acad. Sci. U.S.A. 74, 3081-3085. 
Hughes, J. (1975) Isolation of an endogenous compound from the brain with pharmacological properties similar to morphine. Brain Res. 88, 295-308.

Hughes, J., Smith, T.W., Kosterlitz, H.W., Fothergill, L.A., Morgan, B.A. \& Morris, H.R. (1975) The identification of two related pentapeptides from the brain with potent opiate agonist activity. Nature, Lond. 258, 577-579.

Hughes, J., Kosterlitz, H.W. \& Smith, T.W. (1977) The distribution of methionine-enkephalin and leucineenkephalin in the brain and peripheral tissues. $\mathrm{Br} . J$. Pharmac. 61, 639-647.

Hughes, J., Kosterlitz, H.W., McKnight, A.T., Sosa, R.P., Lord, J.A.H. \& Waterfield, A.A. (1978) Pharmacological and biochemical aspects of the enkephalins. In Centrally Acting Peptides, pp. 179194. Ed. J. Hughes. Macmillan Press Ltd, London.

Jessel, T.M. \& Iversen, L.L. (1977) Opiate analgesics inhibit substance $P$ release from the rat trigemminal nucleus. Nature, Lond. 268, 549-551.

Kosterlitz, H.W. \& Waterfield, A.A. (1975) In vitro models in the study of structure-activity relationships of narcotic analgesics. Ann. Rev. Pharmac. 15, $29-47$.

La Bella, F., Queen, G. \& Senyshyn, J. (1977) Lipotropin: localization by radioimmunoassay of endorphin precursor in pituitary and brain. Biochem. Biophys. Res. Commun. 75, 350-357.

Lazarus, L.H., Ling, N. \& Guillemin, R. (1976) $\beta$ lipotropin as a prohormone for the morphinomimetic peptides endorphins and enkephalins. Proc. natn. Acad. Sci. U.S.A. 73, 2156-2159.

Li, C.H. (1977) $\beta$-Endorphin: a pituitary peptide with potent morphine-like activity. Archs Biochem. Biophys. 183, 592-604.

Li, C.H. \& Chung, D. (1976) Isolation and structure of an untriakontapeptide with opiate activity from camel pituitary glands. Proc. natn. Acad. Sci. U.S.A. 73, $1145-1148$.

Li, C.H., Barnafi, L., Chrétien, M. \& Chung, D. (1965) Isolation and amino-acid sequence of $\beta$ - $L P H$ from sheep pituitary glands. Nature, Lond. 208, 10931094.

Lien, E.L., Fenichel, R.L., Garsky, V., Sarantakis, D. \& Grant, N.H. (1976) Enkephalin-stimulated prolactin release. Life Sci. 19, 837-840.

Loh, H.H., Tseng, L.-F., Wei, E. \& Li, C.H. (1976) $\beta$ Endorphin is a potent analgesic agent. Proc. nat. Acad. Sci. U.S.A. 73, 2895-2898.

Mains, R.E., Eipper, B.A. \& Ling, N. (1977) Common precursor to corticotrophins and endorphins. Proc. natn. Acad. Sci. U.S.A. 74, 3014-3018.

McKnight, A.T., Sosa, R.P., Hughes, J. \& Kosterlitz, H.W. (1978) Biosynthesis and release of enkephalins. In Characteristics and Functions of Opioids, pp. 259-270. Eds J. M. van Ree \& L. Terenius. Elsevier/North Holland Biomedical press, Amsterdam.

Meek, J.L., Yang, H.-Y.T. \& Costa, E. (1977) Enkephalin catabolism in vitro and in vivo. Neuropharmacology 16, 151-154.

Oliver, C., Mical, R.S. \& Porter, J.C. (1977) Hypothalamic-pituitary vasculature: Evidence for retrograde blood flow in the pituitary stalk. Endocrinology 101, 598-604.
Pang, C.N., Zimmerman, E. \& Sawyer, C.H. (1977) Morphine inhibition of the preovulatory surges of luteinizing hormone and follicle stimulating hormone. Endocrinology101, 1726-1732.

Paton, W.D.M. (1957) The action of morphine and related substances on contraction and acetylcholine release of coaxially stimulated guinea-pig ileum. $B r$. J. Pharmac. 12, 119-127.

Pert, C.B. (1976) Behavioural pharmacology of $d-$ alanine ${ }^{2}$-methionine enkephalinamide and other longacting opiate peptides. In Opiates and Endogenous Opioid Peptides, pp. 8-94. Ed. H. W. Kosterlitz. North Holland Publishing Co., Amsterdam.

Pert, C.B., Bowie, D.L., Fong, B.T.W. \& Chang, J.-K. (1976) Synthetic analogues of met-enkephalin which resist enzymatic destruction. In Opiates and Endogenous Opiate Peptides, pp. 79-86. Ed. H. W. Kosterlitz. North Holland Publishing Co., Amsterdam.

Queen, G., Pinsky, C. \& La Bella, F. (1976) Subcellular localization of endorphin activity in bovine pituitary and brain. Biochem. Biophys. Res. Commun. 72, 1021-1027.

Rivier, C., Vale, W., Ling, N., Brown, M. \& Guillemin, R. (1977) Stimulation in vivo of the secretion of prolactin and growth hormone by $\beta$-endorphin. Endocrinology 100, 238-240.

Roberts, J.L. \& Herbert, E. (1977a) Characterization of a common precursor to corticotrophin and $\beta$ lipotropin. Cell-free synthesis of the precursor and identification of corticotropin peptides in the molecule. Proc. natn. Acad. Sci. U.S.A. 74, 48264830.

Roberts, J.L. \& Herbert, E. (1977b) Characterization of a common precursor to corticotropin and $\beta$ lipotropin: Identification of $\beta$-lipotropin peptides and their arrangement relative to corticotropin in the precursor synthesized in a cell-free system. Proc. natn. Acad. Sci. U.S.A. 74, 5300-5304.

Rossier, J., Bayon, A., Vargo, T.M., Ling, N., Guillemin, R. \& Bloom, F. (1977a) Radioimmunoassay of brain peptides: evaluation of a methodology for the assay of $\beta$-endorphin and enkephalin. Life Sfi. 21, 847852.

Rossier, J., French, E.D., Rivier, C., Ling, N., Guillemin, R. \& Bloom, F.E. (1977b) Foot shock induced stress increases $\beta$-endorphin levels in blood but not in brain. Nature, Lond. 270, 618-620.

Rossier, J., Vargo, T.M., Minick, S., Ling, N., Bloom, F.E. \& Guillemin, R. (1977c) Regional dissociation of $\beta$-endorphin and enkephalin contents in rat brain and periphery. Proc. natn. Acad. Sci. U.S.A. 74, 5162-5165.

Rubinstein, M., Stein, S. \& Udenfriend, S. (1978) Characterization of pro-opiocortin, a precursor to opioid peptides and corticotropin. Proc. natn. Acad. Sci. U.S.A. 75, 669-671.

Shaar, C.J., Frederickson, R.C.A., Dininger, N.B. \& Jackson, L. (1977) Enkephalin analogues and naloxone modulate the release of growth hormone and prolactin-evidence for regulation by an endogenous opioid peptide in brain. Life Sci. 21, 853-860.

Simantov, R. \& Snyder, S.H. (1977) Opiate receptor binding in the pituitary gland. Brain Res. 124, 178184. 
Simantov, R., Kuhar, M.J., Uhl, G.R. \& Snyder, S.H. (1977) Opioid peptide enkephalin: immunohistochemical mapping in rat central nervous system. Proc. natn. Acad. Sci. U.S.A. 74, 2167-2171.

Subramanian, N., Mitznegg, P., Sprugel, N., Domsche, S., Würsch, E. \& Demling, L. (1977) Influence of enkephalin on $\mathrm{K}^{+}$-evoked efflux of putative neurotransmitters in rat brain. Arch. Pharmac. 299, 163165.

Taube, H.D., Borowski, E., Endo, T. \& Starke, K. (1976) Enkephalin a potential modulator of noradrenaline release in rat brain. Eur. J. Pharmac. 38, 377-380.

Tseng, L.-F., Loh, H.H. \& Li, C.H. (1976) $\beta$-endorphin as a potent analgesic by intravenous injection. Nature, Lond. 263, 239-240. van Wimersma Greidanus, T.B., Thody, T.J., Verspaget, H., de Rotte, G.A., Goedemans, H.J.H., Croiset, G. \& van Ree, J.M. (1979) Effects of morphine and $\beta$-endorphin on basal and elevated plasma levels of $\alpha$-MSH and vasopressin. Life Sci. 24, 579586.

Waterfield, A.A., Smokcum, R.W.J., Hughes, J., Kosterlitz, H.W. \& Henderson, G. (1977) In vitro pharmacology of the opioid peptides, enkephalins and endorphins. Eur. J. Pharmac. 47, 319332.

Weitzman, R.E., Fisher, D.A., Minick, S., Ling, N. \& Guillemin, R. (1977) $\beta$-endorphin stimulates secretion of arginine vasopressin in vivo. Endocrinology 101, 1643-1646. 